\title{
Effects of Embedded Gravel or Gravel Mulching in Southern Red Soil on Slope Sediment Yield and Runoff
}

\author{
Hui Wang*, Debao Lu, Qian Wang, Chengju Shan \\ College of Water Conservancy and Environmental Engineering, Zhejiang University \\ of Water Resources and Electric Power, Hangzhou, Zhejiang Province, China
}

Received: 3 April 2020

Accepted: 24 May 2020

\begin{abstract}
The red soil hilly region of southern China is affected by rainy seasons (Meiyu periods). There can be large variations of total rainfall per event and rainfall vs. time. This region is therefore sensitive to rainstorms during the Meiyu periods. Rainfall can cause soil coarsening in some areas and the resulting soil contains large amounts of gravel. This form of soil erosion is serious in southern China where there is heavy rainfall and the soil layer is thin. Gravel mulching has been shown to affect soil moisture content, hydraulic conductivity, infiltration, and evaporation. We used simulated rainfall experiments to study the effects of soil surfaces with embedded gravel or gravel mulching on slope runoff and sediment yield for Southern red soils under different rainfall intensities and slope gradients. Both gravel treatments reduced sediment and runoff vs. soil with no gravel, but the amount of reduction varied. Runoff did not consistently increase with slope gradient and rainfall rate. At low rainfall intensity, embedded gravel and gravel mulching inhibited runoff formation, but at high rainfall intensity and steeper slopes, the level of inhibition was reduced. The findings are important for soil conservation and management relative to gravel content, particularly in areas of China with substantial contents.
\end{abstract}

Keywords: gravel, rainfall intensity, slope gradient, red soil, runoff, erosion, sediment

\section{Introduction}

Soil erosion is a serious threat to ecosystem sustainability and it is affected by rainfall characteristics (e.g., rainfall intensity, duration, temporal variation, and velocity) [1-3], underlying surface conditions (e.g., topography, slope gradient, and vegetative cover) [1, 4-8]. Soil erosion has been identified as one of the

*e-mail: wanghui@zjweu.edu.cn major processes contributing to soil and water quality degradation [9-11].

Rainfall intensity and slope gradient are the two dominant influences on hydrologic responses related to soil erosion. They have been studied via numerical simulation, experiments and analytical solutions (e.g., $[1,3,12])$. Rainfall intensity is a dominant factor in rainfall-runoff and soil erosion processes, with higher rainfall intensity generating a larger runoff peak [3]. He et al. (2012) investigated the influence of slope gradient on both runoff and sediment yield under 
various rainfall conditions [13]. They studied six rainfall events, finding that patterns of slope runoff vs. gradient were basically the same, i.e., that runoff increased with steepening gradient and found that rainfall was important to sediment yield. Detachment, transportation, and deposition of soil particles are the three major physical processes related to interactions between rainfall characteristics, overland flow, and soil properties $[5,14,15]$. As a major topographic factor, slope gradient controls soil particle transfer [5, 16-18]. The increased slope gradient is typically associated with greater sediment transport. However, the magnitude of the effect of slope gradient on rainfall-runoff and soil erosion processes is not consistent in experimental studies.

Among soil properties, the gravel content affects erosion. Gravels are mineral particles in soil with a diameter $\geq 2 \mathrm{~mm}$ [19]. In China, $18 \%$ of the soils contain gravel $[20,21]$. These areas include the rocky mountain in southwest Karst regions, cinnamon soil in the northern rocky mountain, purplish soil in southwestern regions, and red hilly soil in southern regions, which contain large amounts of gravel [22, 23]. Gravel mulching can affect soil moisture content, hydraulic conductivity [24, 25], infiltration [26, 27], and evaporation [28], and other soil physical characteristics and hydrologic processes. Some studies indicate that the gravel on the slope may not only promote the infiltration and redistribution of water due to more large pore flow channels $[29,30]$, but also may limit the water infiltration by increasing the curvature of the water flow [31].

The southern red soil hilly region of China is affected by rainy seasons (Meiyu periods) with significant fluctuations in total rainfall and rainfall per unit time. For example, one 60 minutes rainfall in Zhejiang Province during the 2009 Meiyu period was $93 \mathrm{~mm}$ [32]. This makes the region sensitive to rainstorms during the Meiyu periods. Soil coarsening problems exist in some regions and these soils have high proportions of gravel. This form of soil erosion is very serious in areas with heavy rainfall and thin soil layers. The whole hydrological cycle is affected by gravel. Studies of the effects of gravel on water infiltration and evaporation in soil have provided a better understanding of the mechanisms of slope runoff. However, the effects of gravel on slope erosion appear to vary in different areas.

Most studies in China have focused on loess plateaus, with some studies on purplish soil regions [3336]. Zhang et al. (2015) studied the erosion impacts of land use and slope gradient on soil erosion in a red soil hilly watershed and found that soil erosion increased with slope gradient for all land uses [7]. Li et al. (2013) studied erosion effects, using simulated rainfall rates and tillage, on productivity in a subtropical red soil hilly region [36]. Simulated rainfall intensities did not produce significant effects on soil productivity in no-tillage systems but different farming operations produced a significant difference in soil productivity at the same erosion intensity. The effects of rainfall intensity and slope gradient on erosion in a red soil were investigated [37]. Runoff generation of red soil slopes was impacted by both slope angle and rainfall intensity. Runoff rate became steady after an initial unsteady period and increased with increasing rainfall duration. Wang et al. [38] studied the waste slag yard of the development construction project, the results show that the topsoil gravel can trap most of the fine soil particles splashed and reduce the source of sediments washed away by the runoff. The presence of crushed rock has an important impact on the erosion process of slopes such as splash erosion, interrill erosion, gully erosion and other slope erosion processes.

There is no report on the effects or mechanisms of gravel on slope runoff in southern red soil hilly regions. Therefore, research simulating the effects of embedded or mulching gravel in red soil slopes on erosion, runoff, and sediment yield during rainfall is useful. We used simulated rainfall experiments to examine the effects of a soil surface with embedded gravel or gravel mulching on slope runoff and sediment yield for southern red soil. We tested different rainfall intensities and slope gradients. These data enable quantification of soil and water processes on slopes with heterogeneous soil and provides information useful for detailed research and incorporation into soil erosion and slope hydrologic models.

\section{Study Area and Experimental Materials and Methods}

\section{Study Area}

Soil samples were taken from Xinchang County and Linhai County in the eastern coastal province of Zhejiang, China (Fig. 1). Soil at the region is dominated by typical red soils such as pink soil and yellow mud soil with a high content of gravel. Zhejiang is mostly composed of hills, which make up $\sim 70 \%$ of the area. Zhejiang has a humid subtropical climate with four distinct seasons. Spring is rainy with changeable weather. Summer is hot, rainy, and humid. Fall is typically dry, warm and sunny. There is abundant rainfall in early summer. By late summer Zhejiang is threatened by typhoons that form in the Pacific. Average annual temperature is approximately $18^{\circ} \mathrm{C}$. Annual precipitation ranges from 1,000 to $1,900 \mathrm{~mm}$.

\section{Experimental Equipment and Materials}

This experiment was conducted using artificial rainfall simulation equipment. Collection and analysis of runoff sediment samples was carried out simultaneously. Rainfall simulation was performed using a spraytype artificial rainfall system with a rainfall height of $6 \mathrm{~m}$. This ensured that most raindrops could achieve 


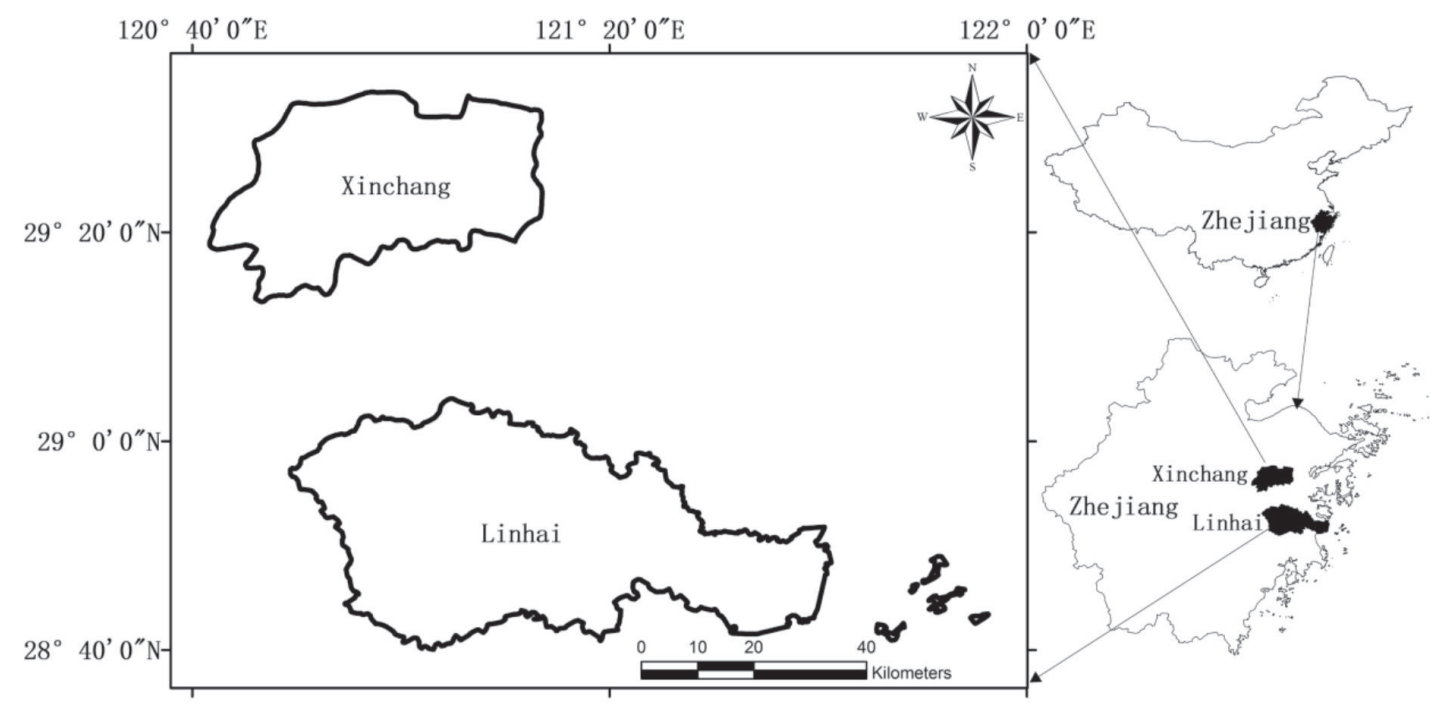

Fig. 1. Map of Xinchang County and Linhai County within Zhejiang Province and of Zhejiang within China.

the terminal velocity. We used a movable hydraulic steel flume with variable slope. The dimensions of the flume were $1.5 \mathrm{~m}$ long, $0.5 \mathrm{~m}$ wide, and $0.35 \mathrm{~m}$ deep. The gradient range was $0-30^{\circ}$. The side of the steel flume was provided with three water outlets: surface runoff (upper), subsurface flow (medium), and underlying infiltration (lower). The test soil was collected from the $0-20 \mathrm{~cm}$ soil layer of natural red soil slopes. The soil was air-dried before passing it through a $6 \mathrm{~mm}$ sieve to remove gravels, roots, and other debris.

The bottom of the flume was covered with $10 \mathrm{~cm}$ of quartz sand when the soil was loaded, to ensure that water infiltrating the flume was drained and the rainfall infiltration and runoff process during the simulation closely matched the actual situation. Filling of the bottom $10-\mathrm{cm}$ soil layer was done by filling and compaction, with bulk density maintained at $1.5 \mathrm{~g} \mathrm{~cm}^{-3}$. The surface $10-\mathrm{cm}$ soil layer or soil and gravel mixture was not compacted. Roughening was done by running a knife crosswise and lengthways on the slope between layers to prevent landslides during rainfall. To eliminate wall effects, soil or soil-gravel mixtures at the boundaries were compacted. Cutting rings with volume $100 \mathrm{~cm}^{3}$ were used to collect soil samples at the top, middle, and bottom of the slope before every rainfall event. The mass of these samples was measured before and after drying, and the bulk density and moisture in an early stage were quantified. This ensured that treatment of the underlying soil-gravel mixture was uniform prior to rainfall.

\section{Experimental Design and Steps}

During the experiment, test gravel with a particle size range of $6-25 \mathrm{~mm}$ was used (gravels of $6-10 \mathrm{~mm}$, 10-20 $\mathrm{mm}$, and $20-25 \mathrm{~mm}$ at a 3:5:2 ratio). The slope gravel content was set to $0 \%$ (blank) and $5 \%$ (for both the mulching and embedded treatments). In the mulching treatment the gravel was placed atop the soil, whereas in the embedded treatment the gravel was mixed with surface soil. Two rainfall intensities (60 and $\left.120 \mathrm{~mm} \mathrm{~h}^{-1}\right)$ and four slope gradients $\left(10^{\circ}, 15^{\circ}, 20^{\circ}\right.$, and $25^{\circ}$ ) were studied. Twenty-four rounds of rainfall experiments were carried out in two parallel flumes. Pre-rainfall on the soil was conducted before the actual rainfall event at a rainfall intensity of $30 \mathrm{~mm} \mathrm{~h}^{-1}$, until there was slope runoff. The experimental sites were undisturbed for $24 \mathrm{~h}$ before the experiment to ensure that the soil moisture content and water distribution were consistent in every experiment. To measure rainfall intensity, four rain gauges were uniformly distributed around the steel flume before actual rainfall treatments. Rainfall uniformity was calculated using the uniformity formula based on rainfall at the various test points. The actual experiment was started once rainfall uniformity reached $>85 \%$. Historical rainfall durations and the slope erosion state of the gravel red soil slopes under various rainfall intensities during preliminary experiments were referenced for rainfall duration, and runoff duration was set to $60 \mathrm{~min}$. After surface runoff started, runoff sediment samples were collected once every minute during the first $10 \mathrm{~min}$. Subsequently, runoff sediment samples were collected every 5 minutes. A stopwatch was used to record the sampling time. After rainfall ended, the volume of runoff samples was measured. The sediment samples were dried in a $105^{\circ} \mathrm{C}$ drying oven to achieve constant weight, and the weight of the dried sediment was weighed. Sediment yield intensity was the weight of dried sediment in runoff sediment samples per unit time $\left(\mathrm{g} \mathrm{min}^{-1}\right)$. The sediment yield per rainfall event at the exit section was taken to be the final volume of soil loss from the flume (g). The surface runoff volume, subsurface flow and underlying infiltration volume from 
Table 1. Runoff-initiating time ( $\mathrm{min})$.

\begin{tabular}{|c|c|c|c|c|}
\hline \multirow{2}{*}{ Soil type } & \multicolumn{4}{|c|}{$60 \mathrm{~mm} \mathrm{~h}^{-1}$ rainfall intensity } \\
\cline { 2 - 5 } & $10^{\circ}$ & $15^{\circ}$ & $20^{\circ}$ & $25^{\circ}$ \\
\hline No gravel & $6.18 \pm 0.71$ & $5.02 \pm 0.30$ & $1.98 \pm 0.59^{\mathrm{b}}$ & $0.32 \pm 0.08^{\mathrm{b}}$ \\
\hline $5 \%$ gravel embedded & $10.38 \pm 1.78^{\mathrm{a}}$ & $7.97 \pm 1.26^{\mathrm{a}}$ & $4.21 \pm 1.51^{\mathrm{b}}$ & $1.35 \pm 0.33^{\mathrm{b}}$ \\
\hline $5 \%$ gravel mulching & $11.50 \pm 1.87^{\mathrm{a}}$ & $8.32 \pm 0.93^{\mathrm{a}}$ & $4.35 \pm 0.33^{\mathrm{a}, \mathrm{b}}$ & $1.50 \pm 0.40^{\mathrm{b}}$ \\
\hline \multirow{2}{*}{ Soil type } & \multicolumn{4}{|c|}{$120 \mathrm{~mm} \mathrm{~h}^{-1}$ rainfall intensity } \\
\cline { 2 - 5 } & $10^{\circ}$ & $15^{\circ}$ & $20^{\circ}$ & $25^{\circ}$ \\
\hline No gravel & $3.17 \pm 0.23$ & $2.13 \pm 0.24$ & $1.02 \pm 0.20^{\mathrm{b}}$ & $0.2 \pm 0.03^{\mathrm{b}}$ \\
\hline $5 \%$ gravel embedded & $8.05 \pm 1.17^{\mathrm{a}}$ & $6.93 \pm 0.33^{\mathrm{a}}$ & $3.53 \pm 0.66^{\mathrm{a}, \mathrm{b}}$ & $0.92 \pm 0.11^{\mathrm{b}}$ \\
\hline $5 \%$ gravel mulching & $8.15 \pm 0.99^{\mathrm{a}}$ & $6.72 \pm 0.82^{\mathrm{a}}$ & $3.7 \pm 0.31^{\mathrm{a}, \mathrm{b}}$ & $0.9 \pm 0.21^{\mathrm{b}}$ \\
\hline
\end{tabular}

Two-way ANOVA showed that soil type $[\mathrm{F}(2,12)=24.28, P<0.01]$ and slope $[\mathrm{F}(3,12)=91.75, P<0.01]$,

but not soil type $\times$ slope interaction $[\mathrm{F}(6,12)=1.884, P=0.17]$ contributed significantly to variations in the runoff-initiating time under $60 \mathrm{~mm} \mathrm{~h}^{-1}$ rainfall intensity; and that soil type $[\mathrm{F}(2,12)=86.14, P<0.01]$, slope $[\mathrm{F}(3,12)=124.1, P<0.01]$,

and soil type $\times$ slope interaction $[\mathrm{F}(6,12)=8.142, P<0.01]$ all contributed significantly to variations in the runoff-initiating time under $120 \mathrm{~mm} \mathrm{~h}^{-1}$ rainfall intensity. No gravel and $10^{\circ}$ were used as the control groups to compare with other soil types and slopes, respectively, and the $P$ values were adjusted by Duncan's multiple comparison correction.

${ }^{\text {a }} P<0.05$, compared with no gravel of the same slope.

${ }^{\mathrm{b}} P<0.05$, compared with $10^{\circ}$ of the same soil type.

the exit section of the flume in every rainfall event was taken to be the final volume $(\mathrm{mL})$.

We analyzed the effects of rainfall intensities of 60 and $120 \mathrm{~mm} \mathrm{~h}^{-1}$ and four slope gradients $\left(10^{\circ}, 15^{\circ}\right.$, $20^{\circ}$, and $25^{\circ}$ ) on runoff and sediment yield for red soil slopes under simulated rainfall conditions and compared differences between embedded gravel or gravel mulching and non-gravel containing slopes.

\section{Results and Discussion}

Before sediment yield and runoff data were collected, we recorded runoff-initiating time (Table 1). Runoff started earlier with higher slope gradient and higher rain intensity. Soil containing gravel, either embedded or mulched, started runoff later than soil without gravel.

We calculated sediment yield intensity $\left(\mathrm{g} \mathrm{min}^{-1}\right)$ over time, at 60 and $120 \mathrm{~mm} \mathrm{~h}^{-1}$ rainfall intensity on no gravel, gravel embedded, and gravel mulching. Fig. 2 shows that there was an increase in sediment yield intensity from $10^{\circ}$ to $25^{\circ}$ slope, under all rainfall and gravel situations, but the curves for the intermediate slopes $\left(10^{\circ}\right.$ and $\left.15^{\circ}\right)$ fluctuated. Embedded gravel reduced the intensity, with the reduction most pronounced at $60 \mathrm{~mm} \mathrm{~h}^{-1}$. Intensity was greater for the higher rain intensity $\left(120 \mathrm{~mm} \mathrm{~h}^{-1}\right)$, for both gravel embedded and gravel mulched.

This study shows the sediment yields (g) for one hour of rainfall (at 60 and $120 \mathrm{~mm} \mathrm{~h}^{-1}$ ), for each of the three gravel situations are shown in Fig 3. The nogravel configuration had much greater sediment yields than either gravel configuration, at both rainfall rates.
At the $60 \mathrm{~mm} \mathrm{~h}^{-1}$ rate, embedded gravel yielded less sediment than mulched gravel, except at the $25^{\circ}$ slope. The opposite was true at $120 \mathrm{~mm} \mathrm{~h}^{-1}$, for all slopes. However, the differences at both rates were much less than those for either gravel situation vs. no gravel.

The greater the rainfall intensity is, the larger the median particle size of the raindrops will be, and the stronger the splashing ability will be, thereby increasing the turbulence of the runoff on the slope [39]. If the kinetic energy of the raindrops is eliminated, the amount of soil erosion will be reduced by $20 \sim 60$ times, or even 90 times [40]. The gravel cover can protect the soil from raindrop splashing, reduce the topsoil crust, and enhance the stability of the surface soil structure [38]. Poesen found that the position of gravel in fine sand has a significant effect on the surface crust strength. The soil crust strength when gravel mulching the ground is weaker than when gravel is embedded in the soil [41]. The relationship between gravel mulching and interrill erosion is complex, which is affected by factors such as topsoil structure, gravel location and size, slope gradient. Gravel mulching can more inhibit the formation of topsoil rill under higher rainfall intensity [39]. The intensity of erosion and sediment yield increases with the increase of slope under the same rainfall intensity, and the influence of this slope varies significantly with the different rainfall intensity [42]. This study shows that the gravel treatment slopes can increase surface infiltration and prevent slope erosion under the lower rainfall intensity. The amount of bare soil is higher than that of mulching gravel slopes due to embedded gravel slopes, which results in higher erosion on the slopes under the higher rainfall intensity. The impact effect of raindrops can form 
$60 \mathrm{~mm} / \mathrm{h}$
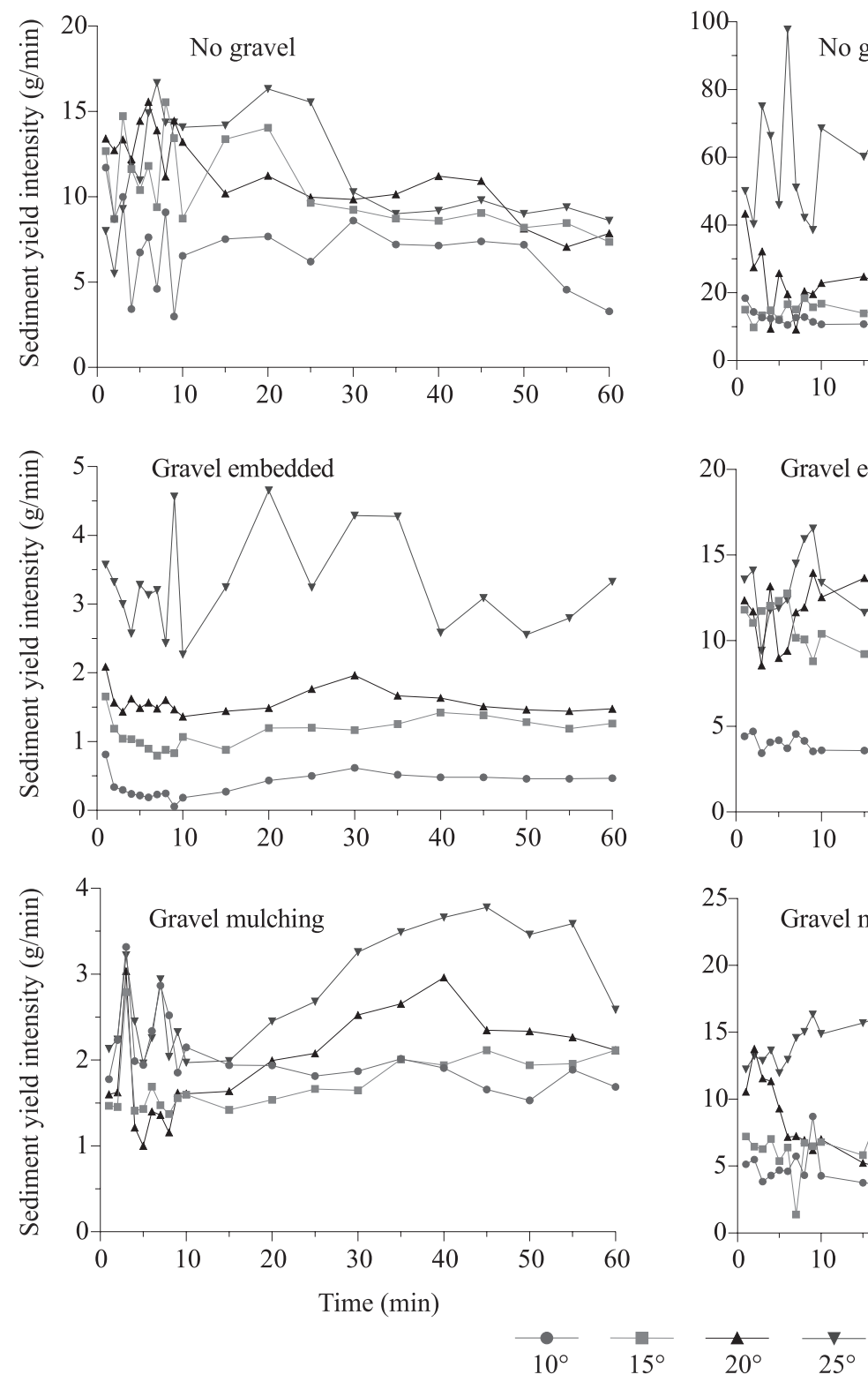

$120 \mathrm{~mm} / \mathrm{h}$
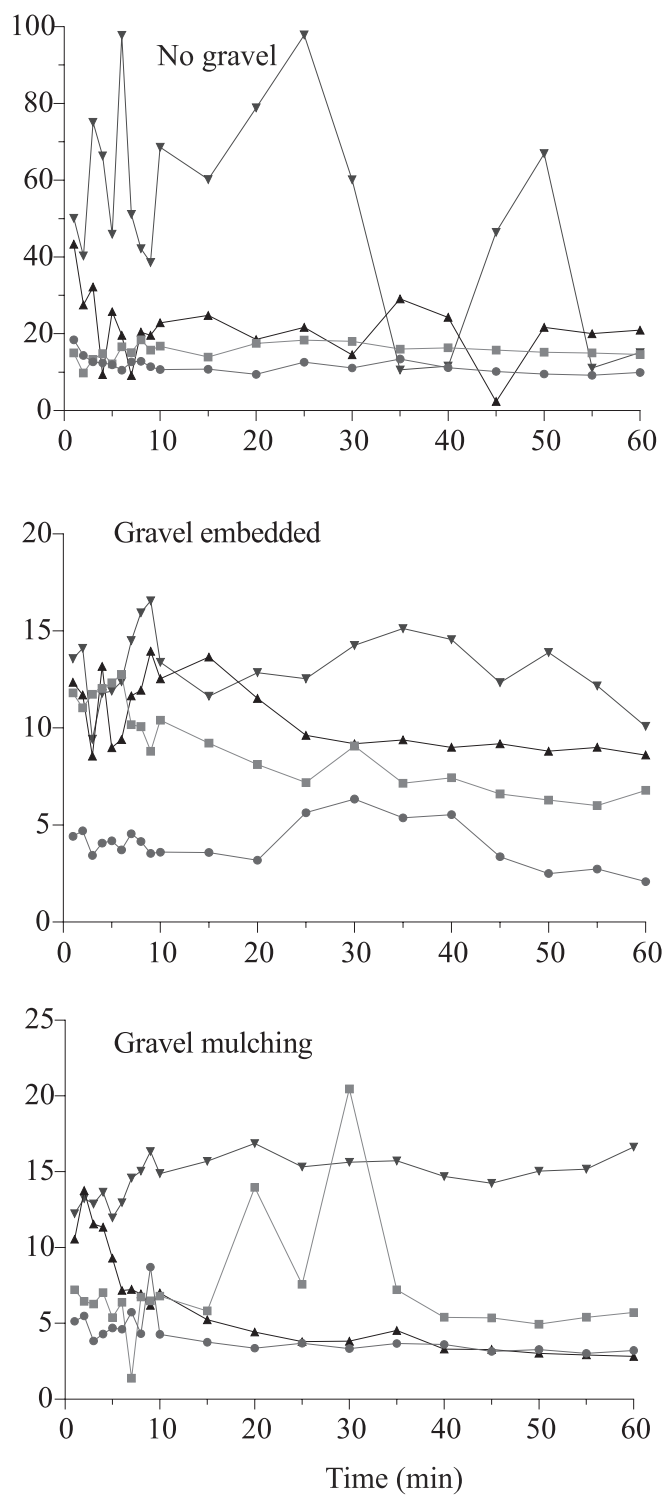

Time (min)

Fig. 2. Sediment yield intensity $\left(\mathrm{g} \mathrm{min}^{-1}\right)$ vs. time at two rainfall intensities (60 and $120 \mathrm{~mm} \mathrm{~h}^{-1}$, left and right panels, respectively) for three gravel situations (no gravel (top panels), gravel embedded (middle panels), and gravel mulching (bottom panels)). Four curves representing different slope gradients are shown by different colors (key at bottom). Each data point is the mean value from two experiments.

a dense temporary crust on the topsoil with the continuous rainfall. So that the soil erosion resistance is enhanced correspondingly and the existence of thin layer water flow, the splashing of rainfall is reduced, and the sediment yield is gradually decreased and stabilized.

The addition of gravel to the soil in this study was a variable along with slope and rainfall intensity. Both mulched and embedded gravel substantially reduced sediment over soil with no gravel. Thus, gravel might produce effects similar to vegetative cover. The contribution rate of slope to runoff and sediment yield is different. The contribution rate of slope to sediment yield is about $30 \%$, and the contribution rate of slope to runoff is about $60 \%$ [43]. In previous research that Komatsu et al. (2018) noted "the effect of slope on runoff generation remains unclear in many different soils including Chinese purple soil" [35]. This might explain some of the variability in runoff and sediment vs. slope. There have also been variable results from other experimental studies evaluating the effects of slope gradient on rainfall-runoff and soil erosion processes.

Runoff distribution is an important parameter, which can reflect the hydrological process of the soil. Due to the existence of gravel, soil properties are different, and its response to rainfall processes and rainfall intensity is different. The effect of rainfall intensity and gravel 


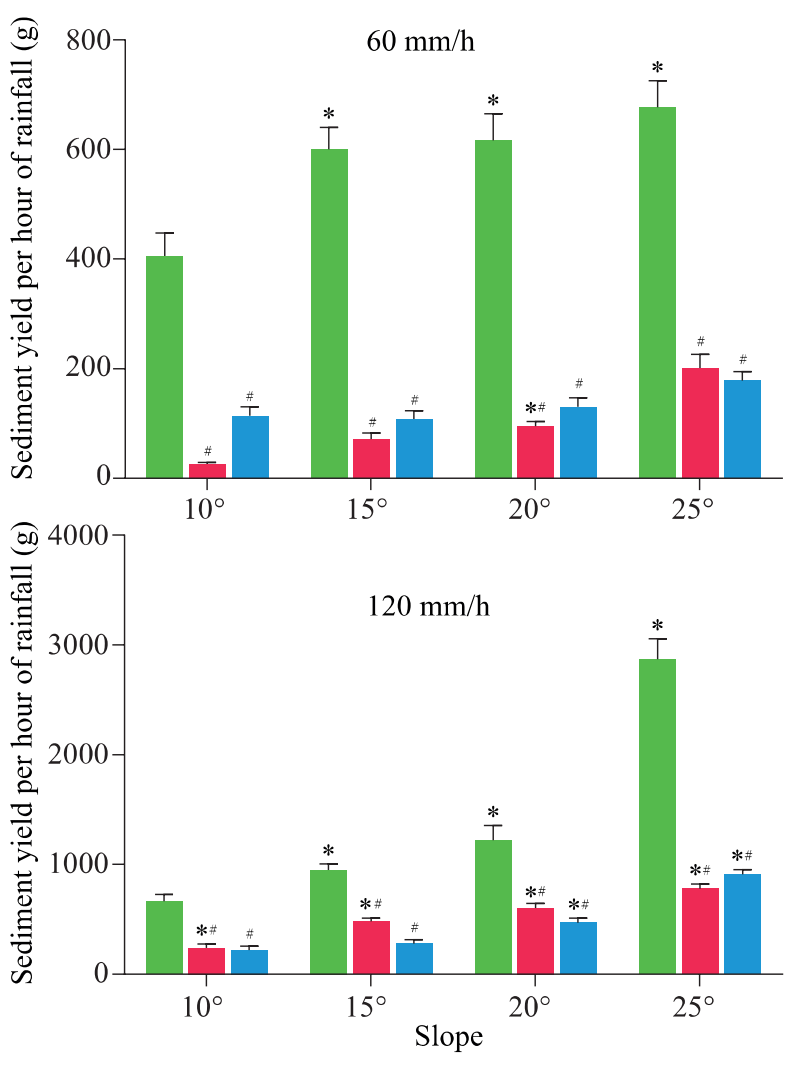

No gravel

Gravel embedded

Fig. 3. Bar graph of sediment yield (g) vs. slope (x-axis) for one hour of rainfall (at rainfall intensities 60 and $120 \mathrm{~mm} \mathrm{~h}^{-1}$, top and bottom panels respectively), for each of the three gravel situations (key at upper right).

Data are presented as mean \pm standard deviation $(\mathrm{n}=2)$. Two-way ANOVA showed that soil type $[\mathrm{F}(2,12)=685.8, P<0.01]$, slope $[\mathrm{F}(3,12)=35.73, P<0.01]$, and soil type $\times$ slope interaction $[\mathrm{F}(6,12)=6.888, P=0.17]$ all contributed significantly to variations in the runoff-initiating time under $60 \mathrm{~mm} \mathrm{~h}^{-1}$ rainfall intensity, and that soil type $[\mathrm{F}(2,12)=389.7, P<0.01]$, slope [F $(3,12)=254.7, P<0.01]$, and soil type $\times$ slope interaction $[\mathrm{F}(6$, $12)=63.08, P<0.01]$ all contributed significantly to variations in the runoff-initiating time under $120 \mathrm{~mm} \mathrm{~h}^{-1}$ rainfall intensity. No gravel and $10^{\circ}$ were used as the control groups to compare with other soil types and slopes, respectively, and the $P$ values were adjusted by Duncan's multiple comparison correction.

${ }^{\#} P<0.05$, compared with no gravel of the same slope.

$* P<0.05$, compared with $10^{\circ}$ of the same soil type.

situation on runoff distribution on the slope is very obvious and the results are shown in Fig. 4. In terms of $10^{\circ}, 15^{\circ}, 20^{\circ}$ and 25 slopes, the ratio of surface runoff is from $47.6 \%$ to $74.2 \%$ under the $60 \mathrm{~mm} \mathrm{~h}^{-1}$ rainfall intensity, which is similar to that of no gravel and gravel embedded slope. The ratio of surface runoff is $56.8 \%-87.9 \%$ on all slopes at $120 \mathrm{~mm} \mathrm{~h}^{-1}$. The ratio of soil subsurface flow with $60 \mathrm{~mm} \mathrm{~h}^{-1}$ rainfall intensity is $4.3 \% \sim 15.5 \%$ on all slopes, and under $120 \mathrm{~mm} \mathrm{~h}^{-1}$, the proportion of the soil subsurface flow is $0.7 \% \sim 5.7 \%$. The proportion of the soil subsurface flow decreases with the increase of the rainfall intensity by $44.2 \% \sim 94.0 \%$. This result shows that the lower rainfall intensity is beneficial to the water infiltration on the soil slope and

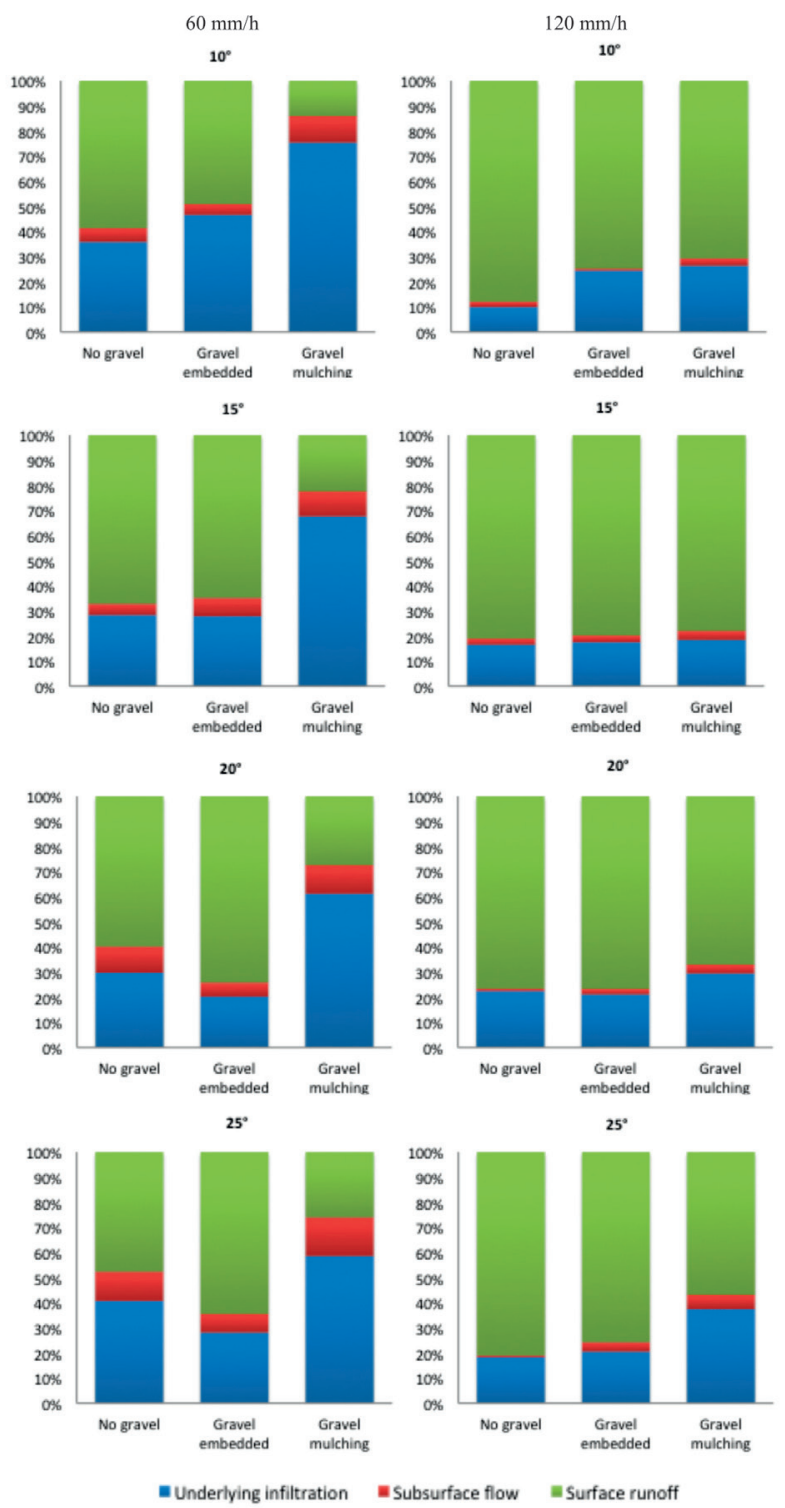

Fig 4. Bar graph of runoff distribution (\%) vs. the three gravel situations (x-axis) at rainfall intensities 60 and $120 \mathrm{~mm} \mathrm{~h}^{-1}$ (left and right panels, respectively), and four slopes $\left(10^{\circ}, 15^{\circ}, 20^{\circ}\right.$, and $25^{\circ}$ ) (key at bottom).

promotes the subsurface flow in the soil. In addition, gravel mulching is beneficial to the development of soil subsurface flow, so the proportion of gravel mulching soil subsurface flow by rainfall at $60 \mathrm{~mm} \mathrm{~h}^{-1}$ is the highest among the test slopes, which are $10.6 \%\left(10^{\circ}\right)$, $10.0 \%\left(15^{\circ}\right) 11.4 \%\left(20^{\circ}\right)$ and $15.5 \%\left(25^{\circ}\right)$ respectively. Under the rainfall intensity of $60 \mathrm{~mm} \mathrm{~h}^{-1}$, the slope change has a greater impact on runoff distribution. The increase of rainfall intensity covers the effect of slope change on runoff distribution of each test slope.

\section{Conclusions}

Gravel, both embedded and mulching in soil, generally reduced sediment and runoff relative to soil 
with no gravel. These two variables had variable levels of reduction. They did not consistently increase with the slope gradient and rainfall rate. At low rainfall intensity, embedded gravel and gravel mulching inhibited runoff formation, but at high rainfall intensity and steeper slopes, the level of inhibition was reduced. The increase of rainfall intensity covers the effect of slope change on runoff distribution of each test slope. Nonetheless, given the comparisons to soil without gravel, gravel might be considered in lieu of (or in addition to) vegetative cover for reducing runoff and sediment. These findings could be useful to researchers and practitioners involved in soil erosion, conservation, and development construction projects management, particularly in areas of southern China with red soil and substantial gravel contents.

\section{Acknowledgments}

This research was supported by National Natural Science Foundation of China (grant Nos. 41701312 and 41702247), Zhejiang Provincial Natural Science Foundation of China (LQ16D010004), project NO. ZJWEU-RWM-20200201A sponsored by the Open Research Fund of the Key Laboratory for Technology in Rural Water Management of Zhejiang province. We would like to thank all partners for their assistance with running the experiments.

\section{Conflict of Interest}

The authors declare no conflict of interest.

\section{References}

1. DONJADEE S., CHINNARASRI C. Effects of rainfall intensity and slope gradient on the application of vetiver grass mulch in soil and water conservation. Int J Sediment Res., 27, 168, 2012.

2. DUNKERLEY D. Effects of rainfall intensity fluctuations on infiltration and runoff: rainfall simulation on dryland soils, Fowlers Gap, Australia. Hydrol Processes, 26, 2211, 2012.

3. RAN Q., SU D., LI P., HE Z. Experimental study of the impact of rainfall characteristics on runoff generation and soil erosion. J Hydrol., 424-425, 99, 2012.

4. ZHAO X.K., LI Z.Y., ROBESON M.D., HU J., ZHU Q.K. Application of erosion-resistant fibers in the recovery of vegetation on steep slopes in the Loess Plateau of China, Catena, 160, 233, 2018.

5. SIRJANI E., MAHMOODABADI M. Effects of sheet flow rate and slope gradient on sediment load. Arab J Geosci., 7, 203, 2014.

6. MOHBOOBEH T., MOHAMMAD H.T., ABDOLMAJID S. Soil erosion risk assessment using GIS and CORINE model: a case study from western Shiraz, Iran. Archives Agro. \& Soi. Sci., 63, 1163, 2017.
7. ZHANG Z., SHENG L., YANG J., CHEN X., KONG L., WAGAN B. Effects of land use and slope gradient on soil erosion in a red soil hilly watershed of Southern China. Sustainability, 7, 14309, 2015.

8. MU W.B., YU F.L., LI C.Z., XIE Y.B., TIAN J.Y., LIU J., ZHAO N.N. Effects of rainfall intensity and slope gradient on runoff and soil moisture content on different growing stages of spring maize. J Water, 7, 2990, 2015.

9. ISSAKA S., ASHRAF M.A. Impact of soil erosion and degradation on water quality: a review. Geol Ecol Landsc., 1, 1, 2017.

10. HE X.L., ZHENG Z.C., LI T.X., HE S.Q. Effect of Slope Gradient on Phosphorus Loss from a Sloping Land of Purple Soil under Simulated Rainfall. Pol. J. Environ. Stud. 29, 1, 2020.

11. LI G.H., VAN ITTERSUM M.K., LEFFELAAR P.A., SATTARI S.Z., LI H.G., HUANG G.Q., ZHANG F.S. A multi-level analysis of China's phosphorus flows to identify options for improved management in agriculture. Agr. Syst, 144, 87, 2016.

12. ASSOULINE S, BEN-HUR M. Effects of rainfall intensity and slope gradient on the dynamics of interrill erosion during soil surface sealing. Catena, 66, 211, 2006.

13. HE J., CAI Q., LIU S. Effects of slope gradient on slope runoff and sediment yield under different single rainfall conditions. Chin. J. Appl. Ecol., 23, 1263, 2012.

14. DEFERSHA M.B., QURAISHI S., MELESSE A.M. The effect of slope steepness and antecedent moisture content on interrill erosion, runoff and sediment size distribution in the highlands of Ethiopia. Hydrol Earth Syst Sci., 15, 2367, 2011.

15. SHI Z.H., FANG N.F., WU F.Z., WANG L., YUE B.J., WU G.L. Soil erosion processes and sediment sorting associated with transport mechanisms on steep slopes. J Hydrol., 454-455, 123, 2012.

16. WANG B., ZHANG G.H., SHI Y.Y., ZHANG X.C. Soil detachment by overland flow under different vegetation restoration models in the Loess Plateau of China. Catena, 116, 51, 2014.

17. STEFANO C.D., FERRO V., PAMPALONE V., SANZONE F. Field investigation of rill and ephemeral gully erosion in the Sparacia experimental area, South Italy. Catena, 101, 226, 2013.

18. JING X.F., CHEN Y.L., PAN C.S., YIN T.W., WANG W.S., FAN X.H. Erosion Failure of a Soil Slope by Heavy Rain: Laboratory Investigation and Modified GA Model of Soil Slope Failure. Int J Environ Res Public Health. 16, 1075, 2019.

19. MILLER F.T., GUTHRIE R.L. Classification and distribution of soils containing rock fragments in the United States. Soil Sci Soc Am J., 13, 1, 1984.

20. LEI Z., HU H., YANG S. A review of soil water research. Advancs in Water Science, 10, 311, 1999.

21. WANG H., LU D.B., XU M.Z. Response of subsurface flow to rainfall intensity in the red soil slope with embedded gravel. Journal of Soil and Water Conservation, 33, 1, 2019.

22. LUO Z.T., NIU J.Z., MENG C., ZHANG Y.H., DU X.Q., LIN X.N., JIA J.W. Effects of distribution of rock fragment on macropores and saturated water conductivity in forest soil in rocky mountain area of northern China. Journal of Soil and Water Conservation, 30, 305, 2016.

23. KANG H.L., WANG W.L., XUE Z.D., GUO M.M., LI J.M., BAI Y., DENG L.Q., LI Y.F., LI Y.L. Effect of gravel on runoff and erosion characteristics on engineering accumulation slope in windy and sandy area. Transactions 
of the Chinese Society of Agricultural Engineering, 3, 18, 2016.

24. LV H.S.,YU Z.B., HORTON R., ZHU Y.H., ZHANG J.Y., JIA Y.W., YANG C.G. Effect of gravel-sand mulch on soil water and temperature in the semiarid Loess region of northwest China. J Hydrol. Eng., 18, 1484, 2013.

25. WANG Y.J., XIE Z.K., MALHI S.S., VERA C.L., ZHANG Y.B. Gravel-sand mulch thickness effects on soil temperature, evaporation, water use efficiency and yield of watermelon in semi-arid Loess Plateau, China. Acta Ecologica Sinica, 34, 261, 2014.

26. WANG X.Y., WANG T.W., CAI C.F., XIE D.T. Processes of rain fall infiltration, runoff and sediment yield on purple soil slope containing rock fragments. Advances in Water Science, 25, 189, 2014.

27. JOMAA S., BARRY D.A., HENG B.C.P., BROVELLI A., SANDER G.C., PARLANGE J.Y. Influence of rock fragment coverage on soil erosion and hydrological response: laboratory flume experiments and modeling. Water Resour Res., 48, W05535, 2012.

28. DIAZ F., JIMENEZ C.C., TEJEDOR M. Influence of the thickness and grain size of tephra mulch on soil water evaporation. Agric Water Manag., 74, 47, 2005.

29. LI Y., LIU J.Z., WEI C.F., GONG J.P., HONG Y.J., YI Z.J., GAO J. Effect of rock fragment content on water infiltration (diffusion) in purple soil. Acta Pedol. Sin., 48, 435, 2011.

30. ZHU Y.J., SHAO M.A. Processes of rainfall infiltration and sediment yield in soils containing different rock fragment contents. Trans. Chin. Soc. Agric. Eng., 22, 64, 2006.

31. SHI Z.J., WANG Y.H., XIONG W., XU L.H., YU P.T., XU D.P. Effect of rock fragments on the formation of soil macroporosity of typical vegetation in Liupan mountains of westnorth of china. Journal of mountain science, 25, $541,2007$.

32. FU X., ZHANG L. Impact of slope length on soil erosion of sloping farmland with crop in red soil hilly region. Trans. Chin. Soc. Agric. Eng., 30, 91, 2014.

33. MUHAMMAD N.K., GONG Y.B., HU T.X., RATTAN L., ZHENG J.K., JUSTINE M.F., MUHAMMAD A., CHE M.X., ZHANG H.T. Effect of slope, rainfall intensity and mulch on erosion and infiltration under simulated rain on purple soil of south-western Sichuan province. China. J Water, 8, 528, 2016.

34. HUANG Y.H., CHEN X.Y., LUO B.L., DING L.Q., GONG C.M. An experimental study of rill sediment delivery in purple soil, using the volume-replacement method. Peer J, 3, e1220, 2015.

35. KOMATSU Y., KATO H., ZHU B., WANG T., YANG F., RAKWAL R. Effects of slope gradient on runoff from bare-fallow purple soil in China under natural rainfall conditions. Journal of mountain science, 15, 738, 2018.

36. LI Z., HUANG J., ZENG G., NIE X., MA W., YU W., GUO W. Effect of erosion on productivity in subtropical red soil hilly region: a multi-scale spatio-temporal study by simulated rainfall. Plos One, 8, e77838, 2013.

37. ZHAO Q., LI D., ZHUO M., GUO T., LIAO Y., XIE Z. Effects of rainfall intensity and slope gradient on erosion characteristics of the red soil slope. Stoch Environ Res Risk Assess., 29, 609, 2015.

38. WANG X.Y., LI C.X., XU Q.X. Review of effects of rock fragment cover on soil water erosion processes. Science of Soil and Water Conservation, 9, 115, 2011.

39. HOU X.L., LV D.Q., WANG H., LIU X.M., LIU C. Effect of slope gradients on rainfall erosion and hydrological process on red soil land-slope. Journal of Irrigation and Drainage, 32, 118, 2013.

40. YANG L., DING S.W. Study on soil erosion of small watershed on GIS and USLE/RUSLE. Drought Environment Monitoring, 25, 24, 2011.

41. POESEN J. Surface sealing as influenced by slope angle and position of simulated stones in the top layer of loose sediments. Earth Surface Processes and Landforms, 11, 1, 1986.

42. CHEN J.J., SUN L.Y., LIU J.T. Effect of slope gradinets on rill erosion under different rainfall intensities and slope lengths. Bulletin of Soil and Water Conservation, 33, 1, 2013.

43. WANG L.Y., ZHA X., HUANG S.Y. Effect of slope gradinets on red soil erosion under different rainfall intensity. Journal of Soil and Water Conservation, 31, 40, 2017. 